Article

\title{
Attitude towards Mobile Learning in English Language Education
}

\author{
Cemil Yurdagül ${ }^{1, *}$ (i) and Saba Öz ${ }^{2, *}$ \\ 1 Vocational School of Justice, Ankara University, 06560 Cebeci/Ankara, Turkey \\ 2 Department of Computer Education and Instructional Technology, Middle East Technical University, \\ 06800 Çankaya/Ankara, Turkey \\ * Correspondence: cyurdagul@ankara.edu.tr (C.Y.); saba@metu.edu.tr (S.O.); Tel.: +90-312-595-52-51 (C.Y.)
}

Received: 22 April 2018; Accepted: 7 July 2018; Published: 10 September 2018

\begin{abstract}
Mobile devices, especially smart phones, are the most frequently used technological devices for daily routines. Mobile devices can be used for various purposes to meet different needs. Since education is a core requirement for human beings, smart phones are being integrated into education. However, it remains to be seen whether they have an impact on learning or not. Consequently, integration of these technologies, or "mobile learning", has become a popular research study in the field of instructional technology. It is important to investigate the impact of smart phones in language education since students today use them frequently. This attitudinal study aims to investigate the attitude of students in higher education towards smart phone use in the context of foreign language learning. In particular, it gathers information about how smart phones are used for language learning. Participants of the study were 294 prep school students from a well-known university in Turkey. Descriptive study was selected as a research method and mixed-method was the research design for the study. The findings of the study showed that participants care about instant and easy access to information in language learning. In addition to drawing attention to the ease of information access, participants provided suggestions about future applications of smartphones in language learning.
\end{abstract}

Keywords: mobile learning; English language teaching; attitude; language learning; smartphone; technology integration

\section{Introduction}

Mobile devices, especially smartphones, are the most frequently used technological devices in daily routines. They have been used for more than three decades since their invention. The first generation of mobile devices are mobile phones, invented in 1990s, through which people could only make a call and send short messages (SMS). As technology improved so fast, mobile phones took smaller and more intelligent forms thus started to be named smartphones. Providing so many advantages, smartphones replaced desktop computers and even notebooks [1,2] (p. 1). They did so because these mobile and functional devices are " ... handheld telecommunication devices that combine miniaturized hardware of a personal computer and a mobile phone with relatively large touch screen" [3] (p. 427).

As a result of rapid development of mobile technologies and their integration into education, the term "mobile learning" emerged. Kukulska-Hulme and Traxler [4] conceptualize mobile learning as "it is certainly concerned with learner mobility, in the sense that learners should be able to engage in educational activities without the constraint of having to do so in a tightly delimited physical location" (p. 1). In their mobile learning concept, it is clear that mobile learning is concerned with learners and learning mobility rather than mobility of technological devices. Within this scope, mobile 
learning covers the mobility of learners, mobility of learning, mobility of educators or instructors and mobility of technological devices [5]. It is noteworthy that mobile learning is not only learning that is based heavily on the use of mobile devices, but also learning that is mediated across contexts using portable technologies [5,6].

Rapid development of mobile technology has sped up the popularity and proliferation of mobile handheld devices. They provide various functions such as voiced navigation for vehicles, communication and network facilities through social media applications (Facebook, Twitter, Instagram, WhatsApp etc.), 3G/4G visual communication, web browsing, online banking, photo and video shooting, sharing applications, and games. At the same time, smartphones are getting more user-friendly and increasing their functionality level. As their functionality continuously expands, they remain efficient and easy to use [7]. That is, users spend less time managing resource access and more time evaluating the value of those resources [8]. Inevitably, they are widely used and becoming a basic need for communicative and technological interactions.

As well as providing mobility, mobile devices offer numerous opportunities. Time of knowledge access, and time and place independency (known as ubiquitous computing) for information search are just two examples. Another term in the related literature for just-in-time knowledge gain is Just-In-Time Learning (JITL) which refers to "brief educational experiences targeted to a specific need" [9]. Furthermore, mobile devices enable individuals to access knowledge practically and on the spot [10]. They also allow access to knowledge everywhere during transportation, during outdoor activities etc. [11]. People can reach information by using mobile devices even while sitting in a restaurant or waiting for a bus without the restrictions of desktop computer technology [8]. Considering all these remarkable advantages of mobile devices, it is possible to predict the extent to which smartphones will be used for educational purposes. For the time being, mobile devices are mostly used for entertainment, information sharing, and connecting to social network sites [12] in leisure times, despite their potential educational advantages and benefits as follows: adaptation of learning to students' learning styles and preferences; interactive learning; multimedia capabilities; ubiquitous Internet connectivity; increased understanding of learning materials; increase in students' motivation; cost-effectiveness; enhanced communication between teachers and students; easy access; student-friendliness; and effective feedback [13-17] (p. 1). Dashtestani states that these advantages and benefits of mobile learning and mobile technologies have already encouraged several educational institutions and organizations to think of mobile technologies as the new learning medium of the current era for both students and instructors and shift their focus from e-learning to mobile learning when designing educational settings. Furthermore, Kinash et al. [18] argue that young generations in particular are already familiar with mobile technologies. Therefore, students should be encouraged to use smartphones to reach and practice learning materials.

Mobile technologies have many advantages for foreign language learning. Thanks to continuous connection to the Internet, students can reach any kind of information everywhere and anytime with respect to language learning. By considering the potential of mobile technologies for language learning, Traxler [19] states that "it is possible to make language learning more authentic, efficient, relevant, and effective by recognizing and responding to universal mobile technologies" (p. 2). Therefore, it is important to provide students with authentic and contemporary language learning environments by benefiting from advantages of mobile technologies. Furthermore, Ogato and Yano [20] claim that mobile technologies are beneficial for language learning since they believe language learning is much more related to context and situations in which learning occurs.

It seems that designers of mobile educational applications are increasingly interested in foreign language learning since students often need to access instant linguistic information, e.g., they look up the meaning of words or conjugation/collocations. However, it is important to conduct some attitudinal and descriptive studies before developing mobile learning applications in a pre-determined subject area to save time and cost. In this regard, learners' perceptions of use of mobile devices for educational purposes should be inspected as it may shed light on their motives for using 
mobile technologies. Moreover, attitudes towards any kind of educational technology could be used to measure to what extent users of such technology (learners and instructors) have ambitions to use the specific technology [5,21]. Ally [2] remarks that the main reason behind the unsuccessful or ineffective implementation of mobile technologies for educational purposes is the attitude of people toward the use of such technologies in education. Therefore, the main purpose of this descriptive study is to inspect the attitude of university-level English language learners towards the use of mobile devices. Indeed, it intends to obtain pre-knowledge about their mobile technology experience in general and in language learning, and elicit their opinions and suggestions, which then will guide further mobile English language learning applications and the related literature. To this end, the study seeks to answers to the following research questions:

RQ1. What is the attitude of prep-school students towards mobile learning?

RQ1a. Is there a significant difference among the students' attitudes towards mobile learning in terms of gender?

RQ1b. Is there a significant difference among the students' attitudes towards mobile learning in terms of faculty?

RQ2. For what purpose do prep-school students use mobile technologies?

RQ3. To what extent do prep-school students use mobile technologies for language learning?

RQ4. Which applications or websites are used by prep-school students in terms of language learning?

RQ5. What are the opinions of prep-school students about the design of mobile learning environments for language learning?

\section{Methodology}

This descriptive study focuses on higher education students' attitude towards mobile learning in English language learning. Since the aim of this study is best fit, embedded type mixed-method research design was applied. Embedded design provides collecting quantitative and qualitative data simultaneously or sequentially just as in parallel or sequential mixed-method design; however, one form of data (qualitative or quantitative) plays a supportive role to other form of data [22]. This is the key point of embedded design, in which both qualitative and quantitative forms of data are collected simultaneously (or sequentially) and results are formed together to explain the research problem. The reason for collecting a second form of data is to enhance or augment findings shown in the first form of data, which can be both qualitative or quantitative, although the more commonly used type in literature is adding qualitative data into quantitative design [22]. For this study, a qualitative form of data was used for augmenting or supporting quantitative form. Quantitative data were obtained from a questionnaire called the mobile learning attitude scale (MLAS) [23] and qualitative data were obtained from taking written responses of students by providing a demographic information form.

\subsection{Sample, Sampling Technique and Study Instrument}

The subjects of the study are 294 prep-school students from the Middle East Technical University (METU), one of the well-known universities in Turkey. Prep-school in higher education means school of foreign language education served for prep-year university students. Among them, 157 are female and 137 are male whose ages are between 18 and 30 (for distribution of ages see Figure 1 below). A convenience sampling approach was used as a sampling technique. There was no criterion for selecting subjects except for being in the same level (pre-intermediate) of English in order to keep consistency among subjects and language level effect minimum. The instruments used in the study are mobile learning attitude scale (MLAS) [23] and demographical information form in which some demographics and open-ended items are involved in order to gather some extra information for the qualitative part of the study. Mobile learning attitude scale [23] consists of 4 sub-factors as advantages of m-learning, constraints of m-learning, usefulness of m-learning, and freedom in m-learning by involving 21 items with a 5-point Likert-type scale. For naming of factors, sub-items combined in the same factor were carefully examined and proposed factor names finalized after taking opinions 
of two different field experts [23]. For the reliability issue of the MLAS, it was shown that MLAS is adequate for differentiating participants with positive attitudes from those possessing negative ones [23]. For the validity of the MLAS, it was shown that scale has a high internal consistency (Cronbach $\alpha=0.88$ ) [23]. A demographical information form was developed by the researchers and includes gender, age, department, frequency of Internet use, and mobile technology use. Moreover, some open-ended items were added in order to support quantitative data by asking the aim of mobile technology use with respect to language learning, benefits of using mobile learning environments, types of mobile applications used for language learning, and design suggestions for a mobile application in foreign language learning.

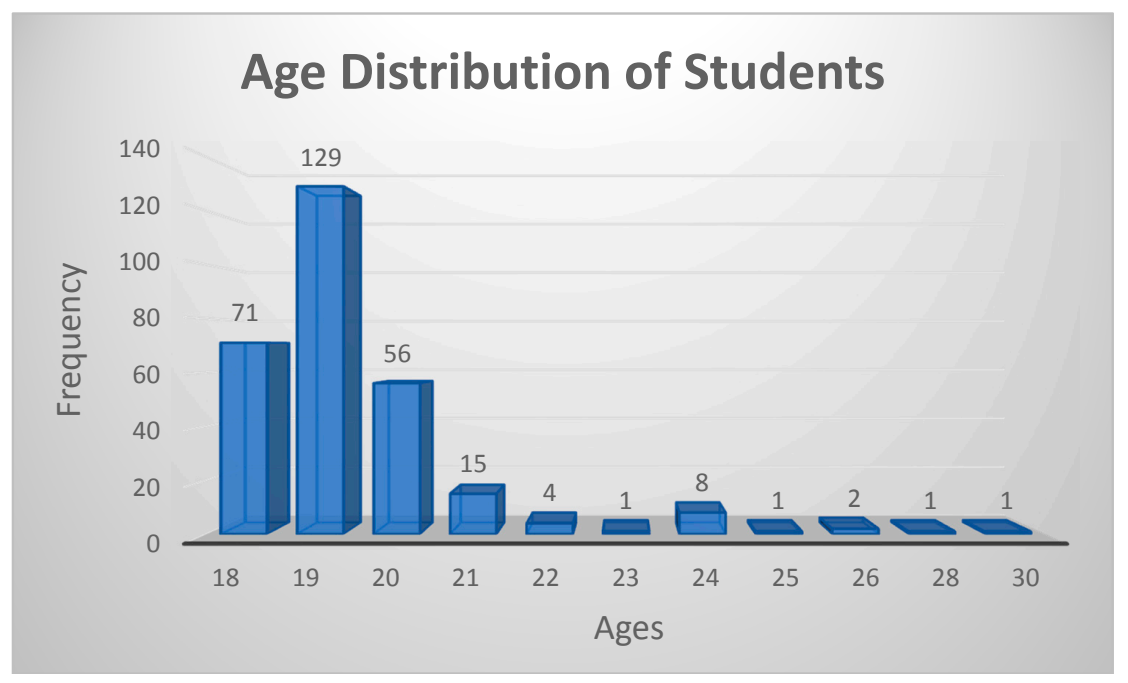

Figure 1. Age distribution of students.

\subsection{Measurement and Analysis}

To answer research questions that form the basis of the study, an independent sample t-test and one-way ANOVA statistical techniques were applied by using the statistical analysis program SPSS. For demographical information (age, gender, faculty, and department), descriptive analysis techniques of SPSS were applied. For qualitative data collected from open-ended questions in the demographical information form, document analysis was conducted. Document analysis was used for extraction of participants' statements related to research questions guiding the study. Therefore, no any special coding technique was applied. Instead, statements provided by the participants were carefully selected by relevance and involved in corresponding sections of results to support descriptive findings.

\section{Results}

\subsection{Demographical Information}

Among the students participating in the study (294 prep-school students), 157 were female and 137 were male. Their ages ranged between 18 and 30 with an average of 19 (Figure 1).

Among participants, 15 (5\%) students were registered to the Faculty of Architecture, $69(24 \%)$ were registered to the Faculty of Arts and Sciences, 38 (13\%) were registered to the Faculty of Economic and Administrative Sciences, 69 (24\%) were registered to the Faculty of Education and 99 (34\%) were registered to the Faculty of Engineering (see Figure 2 below). 


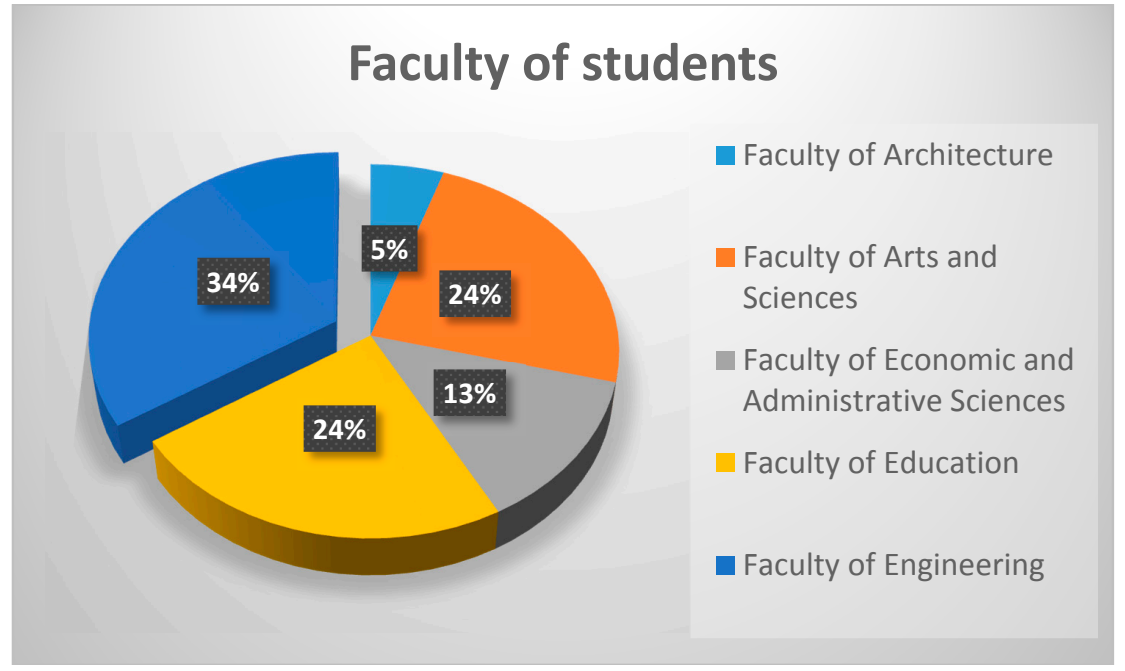

Figure 2. Faculty distribution of students.

\subsection{Results of Qualitative Data Analysis}

Participants provided an item for frequency of Internet use in order to gain an idea about how many hours per day students spend on Internet use. The reason for this was to see their Internet usage, which may guide future design plans for mobile language learning application by deciding whether to design online or offline learning environments. Frequency of their daily Internet use is grouped into 5 categories as: (1) below $1 \mathrm{~h}$ per day; (2) between 1 and $2 \mathrm{~h}$ per day; (3) between 3 and $4 \mathrm{~h}$ per day; (4) between 4 and $5 \mathrm{~h}$ per day; and (5) above $5 \mathrm{~h}$ per day. These are shown below in Figure 3 . Among participants, 10 use the Internet less than $1 \mathrm{~h}$ per day (4\%), 53 use the Internet between 1 and $2 \mathrm{~h}$ per day (18\%), 100 use the Internet between 3 and $4 \mathrm{~h}$ per day (34\%), 62 use the Internet between 4 and $5 \mathrm{~h}$ per day, and 68 use the Internet more than $5 \mathrm{~h}$ per day $(23 \%)$.

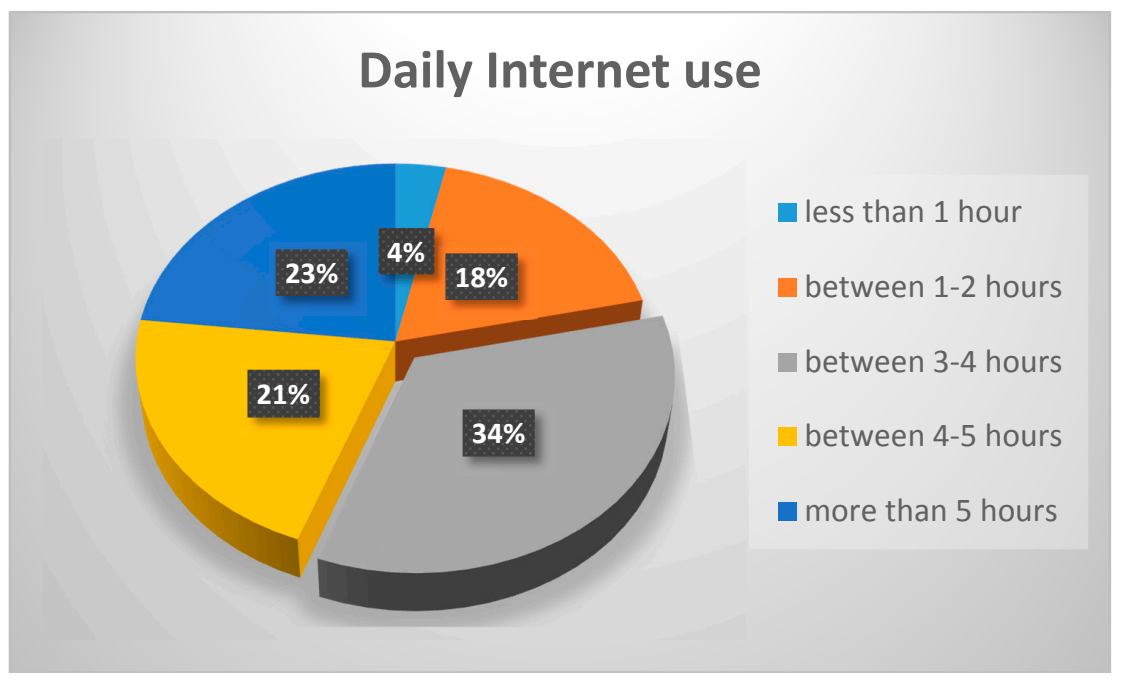

Figure 3. Daily Internet use of students.

Participants were also asked what percent of their total Internet use belongs to their mobile devices in order to inspect the frequency of Internet use by their mobile devices. It was found that 16 met less than $10 \%$ of their total Internet use with their mobile devices, 22 met more than $10 \%$ and less than $30 \%$ of their total Internet use with their mobile devices, 42 met more than $30 \%$ and less than $50 \%$ of their total Internet use with their mobile devices, 58 met more than $50 \%$ and less than $70 \%$ of their total Internet use with their mobile devices, 61 met more than $70 \%$ and less than $90 \%$ of their 
total Internet use with their mobile devices and 95 of them met more than $90 \%$ of their total Internet use with their mobile devices (see Figure 4). This shows that majority of students prefer to use mobile devices for Internet.

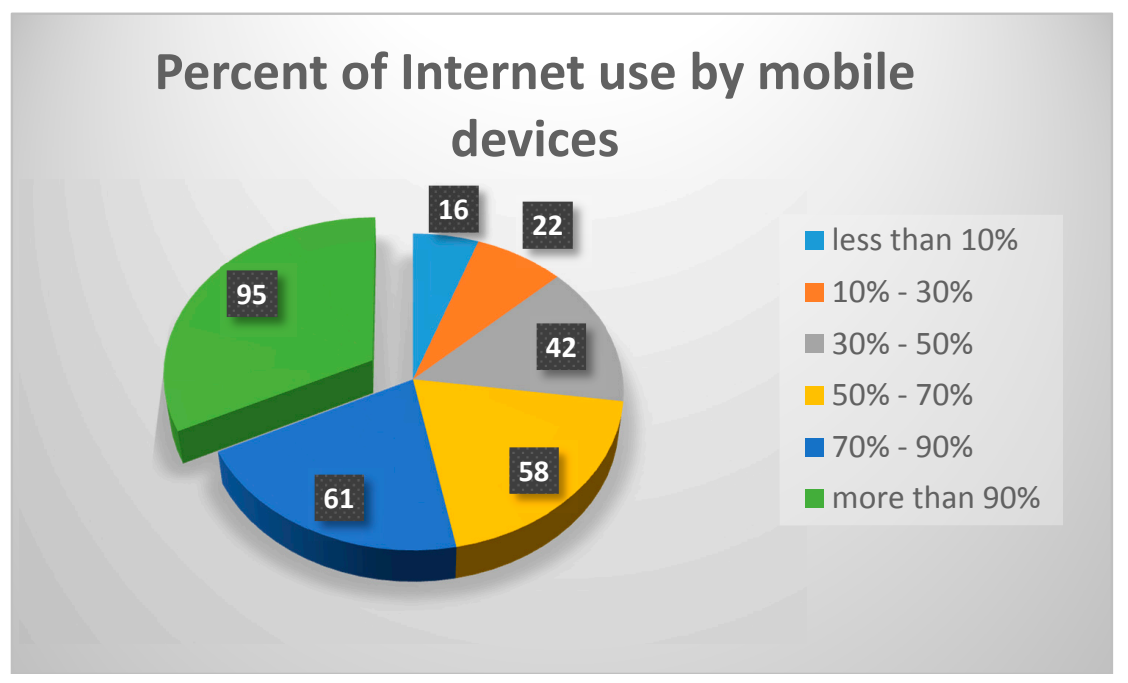

Figure 4. Students' percent of Internet use by mobile devices.

Students were also asked about the purpose of using mobile devices, which is grouped into 4 categories: communication; social media; educational purpose; and other. 257 participants used mobile devices as a communication tool, 251 used mobile devices for social media, and 187 used mobile devices for an educational purpose. This can be interpreted as students preferring to use mobile devices for mostly communicative and social media purposes. Some participants provided other purposes for which they use mobile devices, such as: gaming; banking; online shopping; watching TV or films; listening to music; entertainment; taking photos; and PDF viewing. Students were not only asked about the general purpose of using mobile devices but also they were asked about the aim of using mobile devices in language learning. Students' answers were transcribed into 382 codes and 16 purposes of mobile device use in language learning (see Figure 5). These purposes are given with their corresponding percentages as follows: use of dictionary (55\%); listening to language learning materials $(8 \%)$; topic repetition $(10 \%)$; listening to music $(2 \%)$; watching language learning videos $(2 \%)$; watching films $(4 \%)$; writing practice $(1 \%)$; practicing collocation $(1 \%)$; undertaking research $(1 \%)$; practicing vocabulary $(8 \%)$; reading practice $(1 \%)$; translation $(4 \%)$; pronunciation $(1 \%)$; using language learning applications (1\%); and chatting with foreign friends (1\%). It is necessary to explain two categories in Figure 4 that may cause confusion and seem similar but indeed are not. These are watching films and watching videos. "Watching films" means watching any kind of film which is not directly related to language learning. However, "watching videos" means watching videos for supporting language learning. As seen from the results, the majority of students use mobile devices in language learning for a dictionary. Then topic repetition and listening materials follows.

The subjects were also asked to state their opinions about the advantages of mobile devices, and results are shown below (Figure 6).

As seen from Figure 5, the majority of participants think that mobile devices are advantageous for providing rapid access (44\%) and easy access (26\%) and supportive for leaning (10\%) follows this. Two categories in Figure 5 may seem similar but indeed are not. These are "supportive for learning" and "beneficial for English learning". The reason behind the separation of these categories is that mobile devices can be used for learning everything, whether related to curriculum or not. Therefore, "supportive for learning" refers to learning in general and "beneficial for English learning" specifically refers to the advantage of mobile devices for language learning. Participants also stated 
some opinions about the advantage of mobile devices. Some of statements provided by them are given below:

"Bilgilere hızlıca ulaşıyorum, Tenefüslerde, otobüslerde, otobüs beklerken filan kulanıyorum ve faydalı buluyorum".

"I can access information quickly during break time of my courses, on buses, while waiting for a bus, and I think it is beneficial" (participant 34).

"Kelimelerin anlamlarını daha hızlı öğrenmek için ve bazı grammer konularını tekrar için daha hızlı ulaşabliyorum".

"I can access information quickly in order to learn meanings of words more quickly and to repeat some grammar issues" (participant 78).

"Herşey daha hızlı ve yanımızda istediğimiz an istediğimiz şeye ulaşabiliyoruz".

"Everything is quicker and near us, so we can reach whatever we want whenever we want" (participant 57).

“Hemen elimizin altında sözlük bulunuyor öğretmen olmadığı zaman bir konuyu sorabiliyoruz”.

"With these mobile devices we have a dictionary in our hands so we can reach everything we want to ask when our instructor is not available" (participants 189).

The above statements give a clue about the way mobile devices are used by students. As understood by the statements provided by the students, the main advantage of mobile devices is the quick and easy access to information everywhere. With respect to language learning, mobile devices provide easy ways to look for meanings of words (online dictionaries) and grammar practice.

Participants were asked which websites and mobile applications they use frequently for the purpose of language learning (Table 1). Among their responses, prominent ones are Tureng (an online dictionary) $(46 \%)$, Quizlet (online practical language learning materials) (6\%), TED (expert videos for various topics) $(7 \%)$, Sesli Sözlük (an online dictionary) (5\%) and Google Translate (5\%).

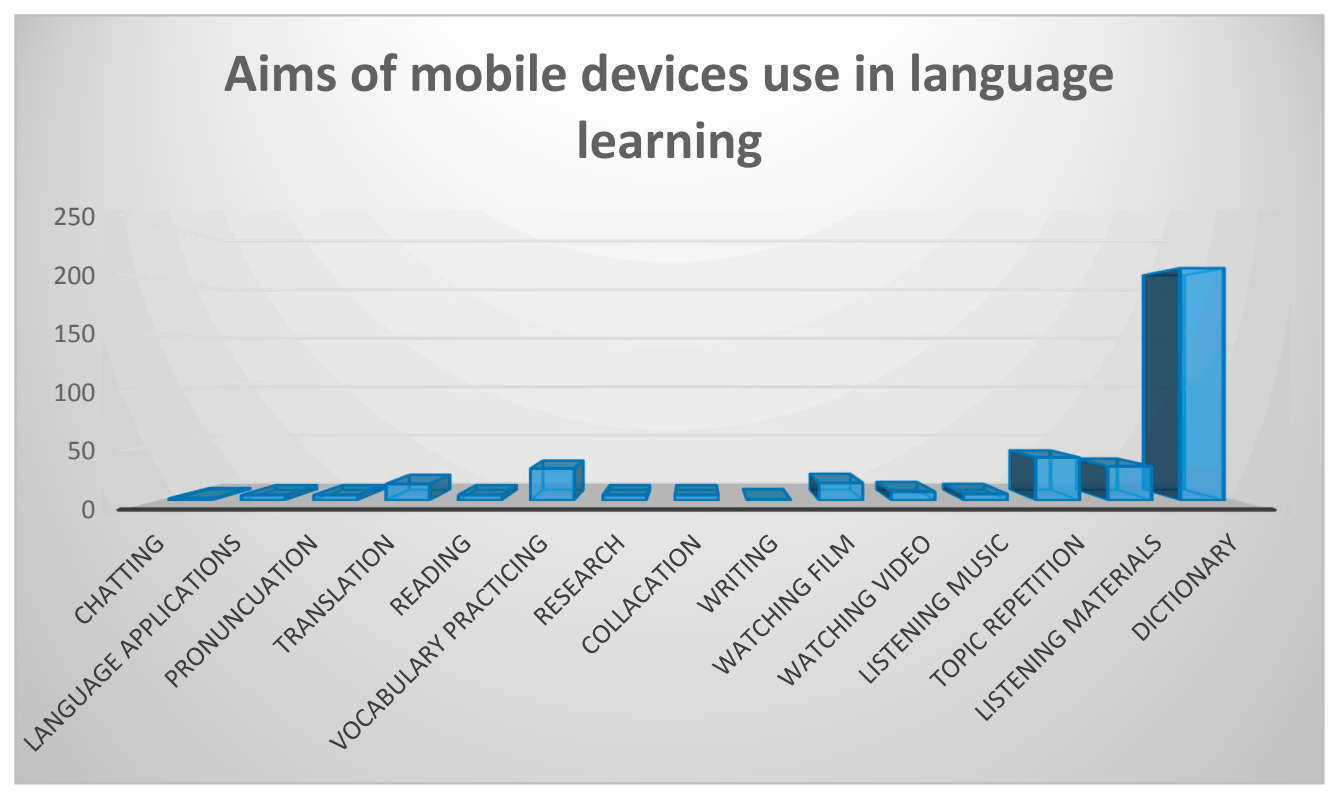

Figure 5. Students' aims of mobile devices use in language learning. 


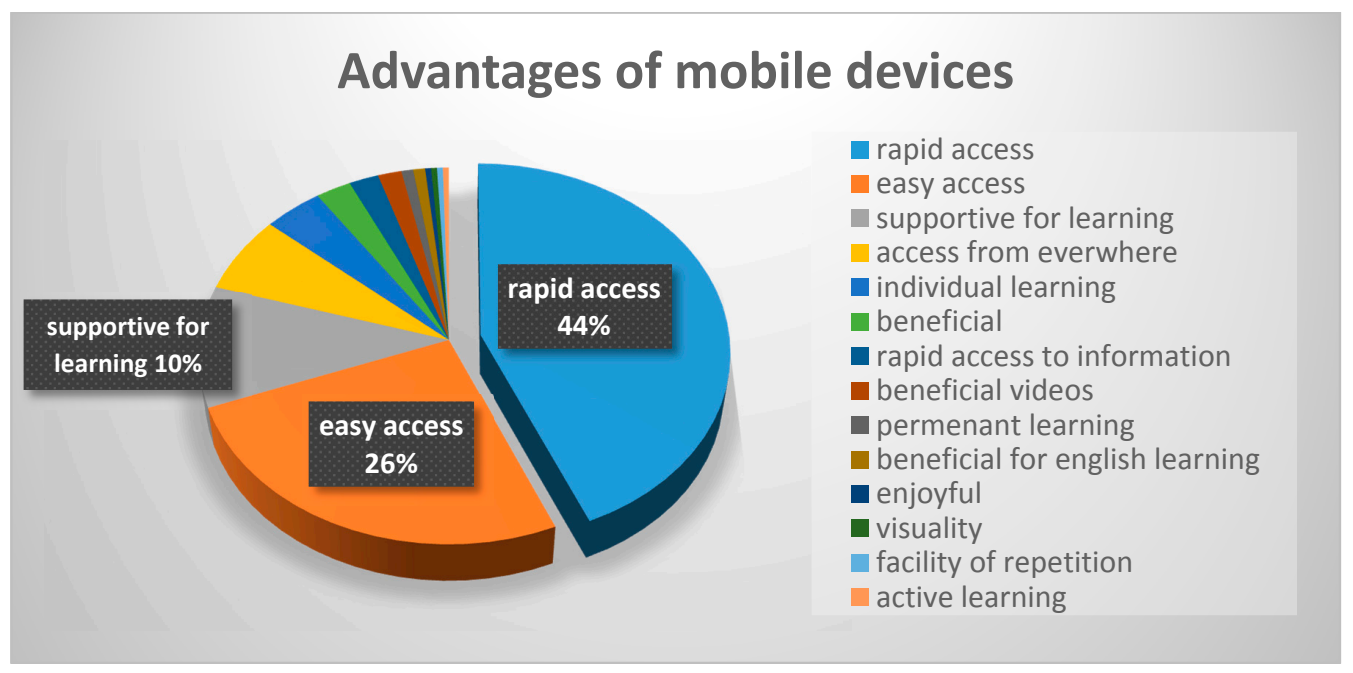

Figure 6. Students' opinions about advantages of mobile devices.

Table 1. Websites and mobile applications used by students for language learning.

\begin{tabular}{cc}
\hline Websites \& Mobile Application & Frequency \\
\hline Tureng & 121 \\
TED & 18 \\
Quizlet & 17 \\
Sesli Sözlük & 14 \\
Google Translate & 13 \\
Oxford Dictionary & 11 \\
British Council & 10 \\
Memrise & 9 \\
Duolingo & 9 \\
Voscreen & 6 \\
Cambridge Dictionary & 6 \\
Longman Active Study Dictionary & 4 \\
Macmillan & 4 \\
LinguaLeo & 3 \\
Yandex & 3 \\
BBC & 3 \\
British Council Podcast & 1 \\
News in Levels & 1 \\
Dyned & 1 \\
Quara & 1 \\
Coursera & 1 \\
Ozdic & 1 \\
WhatsApp & 1 \\
EDx & 1 \\
Meriam Webster & 1 \\
Dictionary & 2 \\
Zargan Dictionary & 1 \\
\hline &
\end{tabular}

When Table 1 is examined overall, it is seen that majority of websites or applications provided by students are based on dictionary use as Tureng, Sesli Sözlük, Oxford Dictionary, Cambridge Dictionary, Longman Active Dictionary, Macmillan, Ozdic, Meriam Webster, and Zargan. Students also provided some translation websites (i.e., Google Translate) and some language practice or online language education websites/applications (i.e., Memrise, Quizlet, Duolingo, LinguaLeo, Dyned). Furthermore, some short video-providing websites/applications for language learning practice were also preferred by students (i.e., TED, Voscreen, BBC, British Council Podcast). Students also preferred to practice their English by using some interactive learning environments such as Quara, through 
which users ask questions and offer answers among themselves. Thinking more comprehensively, some students cited the use of online course enrollment by using well-known websites as Coursera and EDx. Briefly, if websites/applications preferred by students for language learning are grouped into categories, 5 main categories can be made: (1) dictionary/translation; (2) language practicing; (3) video-based language learning; (4) interactive language learning; and (5) online courses.

Opinions of students regarding the design of mobile learning environments in terms of language learning were taken as well (Table 2). They stated 25 design suggestions for mobile applications. Prominent design suggestions are designing a mobile application for vocabulary practicing $(24 \%)$, designing a more effective and useful dictionary (14\%), designing a mobile application for practicing collocations $(9 \%)$ and designing a mobile application for listening practice $(9 \%)$.

Table 2. Opinions of students about the design of mobile learning environment.

\begin{tabular}{cc}
\hline Design Suggestions & Frequency \\
\hline Vocabulary practicing & 23 \\
More effective and useful dictionary & 14 \\
Collocation practicing & 9 \\
Listening practice & 9 \\
Entertainment & 9 \\
Grammar & 6 \\
Speaking practice & 3 \\
Conversation & 3 \\
Reading Practice & 3 \\
Using vocabularies in sentences & 3 \\
Proficiency exam practice & 2 \\
Prioritizing visual memory & 2 \\
e.g., Duolingo & 1 \\
e.g., Voscreen & 1 \\
Consistent with used workbooks & 1 \\
Game-based and pronunciation-based & 1 \\
Chatting and talking with foreign friends & 1 \\
User-friendly and visually rich & 1 \\
Topic-related film and series video parts & 1 \\
Optimum level for all users & 1 \\
Translation & 1 \\
Translation of phrasal verbs & 1 \\
\hline
\end{tabular}

Table 2 offers clues about students' future preferences of mobile device use for language learning. When Table 2 is examined overall, it can be seen that students give importance to vocabulary practice and dictionary use. However, they emphasized that dictionaries should be more effective and useful. They also want to practice language sections such as reading, listening and speaking. Furthermore, they suggested that developers think about exam practice when they develop an application for language learning. Collocations and grammar use are also important topic for language learning and a respectable amount of suggestions are in this direction for developing future language learning mobile applications. Some suggestions are related to designing interactive applications such as question and answer, chatting and talking with foreign friends, game-based and entertaining learning environments. Briefly, students demand more beneficial, user-friendly and at the same time entertaining mobile learning environments for English language practice instead of book-based and non-interactive ones.

Some statements provided by students with respect to suggestions for future design of mobile learning environments regarding foreign language learning are given below:

“Kelimeleri cümle içinde kullanan bir uygulama çünkü bazı kelimelerin collocationları var"

"An application that uses vocabularies in sentences since some words have their collocations."

(participant 179) 
“Online yarışma şeklinde bu şekilde daha kolay bağımlılık yapıyor ve öğrenmek için değil eğlenmek için gelindiğinde daha etkili oluyor"

"I like online competitions since they make us more dependent on engaging in that way and when we use them for entertainment purposes rather than learn something, it is more effective." (participant 264)

"Çok amaçlı bir sözlük tasarlardım.Her sözcük için kurulu cümlelerin olduğu, hem türkçesinin hem ingilizcesinin ve bütün kullanımlarının oldugu bir uygulama tasarladım."

"I may design a multi-purpose dictionary application in which there are example sentences for each word, Turkish and English equivalents of each word, and their usage as well." (participant 91)

The above statements provided by students with respect to design suggestions for future mobile foreign language learning environments shows that students put more emphasis on practicing some specific language sections such as collocations and vocabulary use in sentences. Furthermore, it is possible to say in light of given suggestions that students prefer to learn/practice English by entertainment such as competition rather than focusing on learning something.

\subsection{Results of Quantitative Data Analysis}

Quantitative data obtained from the mobile learning attitude scale were used to answer the first research question, which tries to discover whether there is a significant difference among the students' attitudes towards mobile learning in terms of their gender and faculty. To clarify this, an independent t-test and one-way ANOVA techniques were applied.

The independent t-test was applied in order to clarify whether there are significant differences among the students' attitudes towards mobile learning in terms of gender (Table 3), and the result showed that there is not a significant difference between male students' $(M=2.83, S D=0.63)$ attitude towards mobile learning and female students' $(M=2.72, S D=0.56)$ attitude towards mobile learning $t(292)=-1.52, p=0.13$.

One-way analysis of variance was conducted in order to examine whether there is a significant difference among students regarding attitude towards mobile learning in terms of faculties. The dependent variable was the attitude towards mobile learning score. The independent variable was the faculties of students, which included five levels (Table 4) as follows: faculty of architecture $(M=2.77$, $S D=0.46)$; faculty of arts and sciences $(M=2.60, S D=0.61)$; faculty of economics and administrative sciences $(M=2.71, S D=0.63)$; faculty of education $(M=2.89, S D=0.52)$; and faculty of engineering $(M=2.82, S D=0.61)$. The results of ANOVA showed that there is a significant difference among students' attitude towards mobile learning in terms of faculties, $\mathrm{F}(4285)=2.49, p<0.05, \eta^{2}=0.03$. The strength of relationship between the faculty groups and the attitude score of students toward mobile learning as assessed by $\eta^{2}$, was low, with the faculty groups accounting for $3 \%$ of the variance of the dependent variable (Table 5). Post-hoc comparisons indicated that the mean score for the faculty of education group $(M=2.89, S D=0.52)$ was significantly different from the faculty of arts and sciences $(M=2.71, S D=0.63)$.

Table 3. $t$-test result of comparing males and females on attitude towards mobile learning.

\begin{tabular}{cccccccc}
\hline Gender & $\boldsymbol{n}$ & Mean & $\boldsymbol{S D}$ & $\boldsymbol{t}$-cal & $\boldsymbol{t}$-crit & $d f$ & $\boldsymbol{p}$ \\
\hline Female & 157 & 2.72 & 0.56 & -1.52 & 1.96 & 292 & 0.13 \\
Male & 137 & 2.83 & 0.63 & & & & \\
\hline
\end{tabular}


Table 4. Faculty distribution among students.

\begin{tabular}{cccc}
\hline Faculty Groups & Mean & SD & $\boldsymbol{n}$ \\
\hline Faculty of Architecture & 2.77 & 0.46 & 15 \\
Faculty of Arts and Sciences & 2.60 & 0.61 & 69 \\
Faculty of Economics and Administrative Sciences & 2.71 & 0.63 & 38 \\
Faculty of Education & 2.89 & 0.52 & 69 \\
Faculty of Engineering & 2.82 & 0.61 & 99 \\
\hline
\end{tabular}

Table 5. One-way ANOVA results comparing faculties of students on attitude towards mobile learning.

\begin{tabular}{cccccc}
\hline Source & $S S$ & $d f$ & $M S$ & $\boldsymbol{F}$ & $\eta^{2}$ \\
\hline Faculty group & 3.44 & 4 & 0.86 & $2.49 *$ & 0.03 \\
Error & 98.34 & 285 & 0.35 & & \\
Total & 101.78 & 289 & & & \\
\hline \multicolumn{5}{c}{$p<0.05}$.
\end{tabular}

\section{Discussion and Conclusions}

This study aims to explore attitudes of prep-school students towards mobile learning in order to gain deep insight about their point of view before designing and developing such language learning mobile applications. Participants were given a demographical information form and an attitude towards mobile learning scale. By analyzing quantitative and qualitative data obtained from these instruments, 5 research questions that form the basis of the study were asked. The results of study are discussed below in line with these questions:

RQ1a. Comparing males and females in terms of attitude towards mobile learning

Analysis result showed that there is no significant difference between male and female students' attitudes towards mobile learning. Similarly, some scholars have not found significant differences among students' attitudes toward the use of mobile learning in terms of their gender [5,24-26]. Furthermore, Uzunboylu, Cavus and Ercag [27] did not find significant difference between male students and female students in terms of the usefulness of mobile learning system [28] scores. Moreover, Rees and Noyes [29] did not find any difference between female and male mobile phone use. On the other hand, some researchers claim the opposite by indicating significant differences among the students' attitudes toward the use of mobile learning in terms of their gender, where female students were more positive towards the use of mobile phones compared to their male peers [30,31]. In terms of mobile phone use, Rees and Noyes found an interesting result that suggested males use voice calling more than females, while females use SMS more than males [29]. This may give a clue about males being prone to oral communication rather than written communication. Concerning gender, Skog [32] found that preferences of mobile phone differs as males focused on technical functions while females give importance to social aspects [33] (p. 283). Furthermore, in their descriptive study about students' mobile learning practices in higher education, Chen and Denoyelles [34] found that in terms of gender difference, males tended to use mobile devices for academic purposes more than females.

RQ1b. Comparing Faculties in terms of attitude towards mobile learning

Results showed that there is a significant difference among students' attitude towards mobile learning in terms of their faculty. In particular, it was observed that attitude score of students whose majors are from the faculty of education is greater than students whose majors are from the faculty of arts and sciences. Although it is hard to surmise certainly about this issue, it can be claimed that students from faculty of education are more prone to use of language learning-themed mobile applications than students from the faculty of arts and sciences. On the other hand, Al-Emran, Elsherif, and Shaalan [5] found that there are no significant differences among students' attitude toward mobile 
learning in terms of their academic majors. In terms of academic year, Chen and Denoyelles [34] found that freshmen and sophomores tended to use mobile devices in their courses more often than juniors and seniors. These results coincide with the result of this study in some way since the students participating in the current study are in the first year of their study at university.

RQ2. Purpose of using mobile technologies

Results showed that mobile technologies are mostly used for communication and social media purposes. In addition to these, mobile technologies are also used incontrovertibly by participants for an educational purpose. Apart from these, results of the study also showed that mobile technologies are used for different purposes such as gaming, banking, online shopping, watching TV or films, listening to music, entertainment, taking photos, and PDF viewing. In addition to these forms of mobile technology use, participants also stressed the quick access to the any kind of information through these kinds of technologies everywhere and at any time. This finding is parallel with Al-Fahad's [35] study which states that "mobile technologies are more flexible and enable students greater freedom of learning any place, any time" (p. 114).

RQ3. Purpose of using mobile technologies regarding language learning

In terms of language learning, it was found that mobile technologies are used by participants for different purposes in terms of language learning and language practicing. These purposes can be listed as follows: use of dictionary; listening language learning materials; making topic repetition; listening to music; watching language learning videos; watching films; writing practice; practicing collocation; making research; practicing vocabulary; reading practice; translation; pronunciation; using language learning applications; and chatting with foreign friends. In addition, participants stated that language learning is more entertaining when sharing information through chatting and competing. This finding coincides with the study of Chen and Denoyelles [34] which states that students perceived mobile technologies as powerful learning aids in terms of easy knowledge sharing and retrieval.

\section{RQ4. Applications and websites used for language learning}

Results showed that students mostly used Tureng, Quizlet, TED, Sesli Sözlük (an online dictionary website designed in Turkey) and Google Translate. In addition to them, Oxford Dictionary, British Council, Memrise and Cambridge Dictionary websites were used most by prep-school students. These results can be interpreted as students using their mobile devices to look up the meaning of English words most of the time during their exposure to language learning. On the other hand, the result of the study shows that students also use some other applications for language practice such as Duolingo and Voscreen, in which users are being exposed to language quizzes with multiple-choice and fill-in-the blank items. Some interactive language practicing environments were also preferred by prep school students and this shows that rather than practicing book-based exercises, students seeks interactivity in the form of question and answer, and chatting with friends in other cultures.

RQ5. Design suggestions for mobile application regarding language learning

The results of the study showed that students mostly seek and demand vocabulary practicing applications, which should be more effective and useful. Furthermore, students stressed practicing collocations and listening practice. In addition to all of these, students showed that they are more likely to prefer learning and practicing English language in entertaining applications/environments such as gaming, chatting and competing. Therefore, it is important to consider interactivity and entertainment by gaming or contests in order to keep students engaged in such language learning environments.

In line with the findings of the study, it can be claimed that students effectively use their mobile devices to practice vocabulary by looking at online dictionary websites and applications. This gives a clue to designers of language learning mobile applications that vocabulary practice is the most needed issue by language learners. To do that, a mobile application in design and development stage should involve everything about vocabulary practice such as meanings of the words, collocations 
of words, pronunciation of words, and their use in sample sentences. Furthermore, findings of the study also showed that students can engage in language quiz shows that involve different quiz types as multiple-choice, fill-in-the blanks, matching, drag-and-drop items and translation questions after watching or listening to short conversations collected from different films, series and TV programs. Therefore, the main issue which should be addressed by designers in terms of language learning is vocabulary and translation. Since entertainment and interactivity were also emphasized by students, designers of such mobile language learning environments should also take these suggestions into consideration. For future research, scholars may involve participants from other universities or the same age group of English language learners to compare the results of this study, in particular in light of students' tendency toward mobile device use regarding English language learning. Furthermore, a follow-up study or a systematic review study analyzing studies covering a variety of contexts may also be conducted to see if the trend revealed from the current study is general.

Author Contributions: Data Analysis, C.Y.; Writing—original draft, S.Ö.; Writing—review and editing, S.Ö.

Funding: This research received no external funding.

Acknowledgments: Thanks to school personnel for their valuable contribution during data collection.

Conflicts of Interest: The authors declare no conflict of interest.

\section{References}

1. Faille, M.; Morrison, K. Rise of the Mobile Phone. National Post. 5 April 2013. Available online: http://news. nationalpost.com/2013/04/05/graphic-rise-of-the-mobile-phone/ (accessed on 20 April 2018).

2. Ally, M. Mobile learning: From research to practice to impact education. Learn. Teach. High. Educ. Gulf Perspect. 2013, 10, 1-10.

3. Kulendran, M.; Lim, M.; Laws, G.; Chow, A.; Nehme, J.; Darzi, A.; Purkayastha, S. Surgical smarthphone applications across different platforms: Their evaluation, uses, and users. Surg. Innov. 2014, 21, 427-440. [CrossRef] [PubMed]

4. Kukulska-Hulme, A.; Traxler, J. Mobile Learning: A Handbook for Educators and Trainers; Routledge: London, UK, 2005.

5. Al-Emran, M.; Elsherif, H.M.; Shaalan, K. Investigating attitudes towards to use of mobile learning in higher education. Comput. Hum. Behav. 2016, 56, 93-102. [CrossRef]

6. Matias, A.; Wolf, D.F. Engaging students in online courses through the use of mobile technology. Cut.-Edge Technol. High. Educ. 2013, 6, 115-142.

7. Nassuora, A.B. Students' acceptance of mobile learning for higher education in Saudi Arabia. Am. Acad. Sch. Res. J. 2012, 4, 24-30. [CrossRef]

8. Caudill, J.G. The growth of m-learning and the growth of mobile computing: Parallel developments. Int. Rev. Res. Open Distance Learn. 2007, 8. [CrossRef]

9. Davis, J.S.; Garcia, G.D.; Wyckoff, M.M.; Alsafran, S.; Graygo, J.M.; Withum, K.F.; Shulman, C.I. Use of mobile learning module improves skills in chest tube insertion. J. Surg. Res. 2012, 177, 21-26. [CrossRef] [PubMed]

10. Kukulska-Hulme, A.; Traxler, J. Learning Design with Mobile and Wireless Technologies. In Rethinking Pedagogy for the Digital Age; Beetham, H., Sharpe, R., Eds.; Routledge: London, UK, 2007; pp. 180-192.

11. Shudong, W.; Higgins, M. Limitations of mobile phone learning. In Proceedings of the IEEE International Workshop on Wireless and Mobile Technologies in Education (WMTE 2005), Tokushima, Japan, 28-30 November 2005.

12. Iqbal, S.; Qureshi, I.A. M-Learning adoption: A perspective from a developing country. Int. Rev. Res. Open Distance Learn. 2012, 13, 147-164. [CrossRef]

13. Kukulska-Hulme, A.; Shield, L. An overview of mobile assisted language learning: From content delivery to supported collaboration and interaction. ReCALL 2008, 20, 271-289. [CrossRef] 
14. Milrad, M.; Jackson, M. Designing and implementing educational mobile services in university classrooms using smart phones and cellular networks. Int. J. Eng. Educ. 2008, 24, 84-91.

15. Stockwell, G. Using mobile phones for vocabulary activities: Examining the effect of the platform. Lang. Learn. Technol. 2010, 14, 95-110.

16. Walker, R. "I don't think I would be where I am right now". Pupil perspectives on using mobile devices for learning. Res. Learn. Technol. 2013. [CrossRef]

17. Dashtestani, R. Moving bravely towards mobile learning: Iranian students' use of mobile devices for learning English as a foreign language. Comput. Assist. Lang. Learn. 2015, 29, 815-832. [CrossRef]

18. Kinash, S.; Brand, J.; Mathew, T. Challenging mobile learning discourse through research: Student perceptions of Blackboard Mobile Learn and iPads. Australas. J. Educ. Technol. 2012, 28, 639-655. [CrossRef]

19. Traxler, J. Mobile Learning for Languages: Can the Past Speak to the Future? The International Research Foundation for English Language Education: Monterey, CA, USA, 2013; Available online: https:/ / www.tirfonline.org/wpcontent/uploads/2013/11/TIRF_MALL_Papers_Traxler.pdf (accessed on 20 April 2018).

20. Ogata, H.; Yano, Y. Knowledge awareness for computer-assisted language learning using hand-helds. Int. J. Learn. Technol. 2005, 5, 435-449.

21. Ardies, J.; De Maeyer, S.; Gijbels, D.; van Keulen, H. Students' attitudes towards technology. Int. J. Technol. Des. Educ. 2014, 1-23. [CrossRef]

22. Creswell, J.W. Educational Research: Planning, Conducting and Evaluating Quantitative and Qualtiative Research; Pearson: London, UK, 2012.

23. Çelik, A. M-Learning attitude scale: Validity and realiability analyses. J. Res. Educ. Teach. 2013, 4, 172-185.

24. Cavus, N. Investigating mobile devices and LMS integration in higher education: Student perspectives. Procedia Comput. Sci. 2011, 3, 1469-1474. [CrossRef]

25. Wang, Y.S.; Wu, M.C.; Wang, H.Y. Investigating the determinants and age and gender differences in the acceptance of mobile learning. Br. J. Educ. Technol. 2009, 40, 92. [CrossRef]

26. Yang, S.H. Exploring college students' attitudes and self-efficacy of mobile learning. Turk. Online J. Educ. Technol. 2012, 11, 148.

27. Uzunboylu, H.; Cavus, N.; Ercag, E. Using mobile learning to increase environmental awareness. Comput. Educ. 2009, 52, 381-389. [CrossRef]

28. Motiwalla, L.F. Mobile learning: A framework and evaluation. Comput. Educ. 2007, 49, 581-596. [CrossRef]

29. Rees, H.; Noyes, J.M. Mobile telephones, computers and the Internet: Sex differences in adolescents' use and attitudes. Cyber Psychol. Behav. 2007, 10, 482-484. [CrossRef] [PubMed]

30. Khaddage, F.; Knezek, G. iLearn via mobile technology: A comparison of mobile learning attitudes among university students in two nations. In Proceedings of the IEEE 13th International Conference on Advanced Learning Technologies (ICALT), Beijing, China, 15-18 July 2013; pp. 256-258.

31. Taleb, Z.; Sohrabi, A. Learning on the move: The use of mobile technology to support learning for university students. Procedia-Soc. Behav. Sci. 2012, 69, 1102-1109. [CrossRef]

32. Skog, B. Mobiles and the Norwegian teen: Identity, gender, and class. In Perpetual Contact: Mobile Communication, Private Talk, Public Performance; Katz, J.E., Aakhus, M.A., Eds.; Cambridge University Press: Cambridge, UK, 2002; pp. 255-273.

33. Campbell, S.W. Perceptions of Mobile Phones in College Classrooms: Ringing, Cheating, and Classroom Policies. Commun. Educ. 2006, 55, 280-294. [CrossRef]

34. Chen, B.; Denoyelles, A. Exploring Students' Mobile Learning Practices in Higher Education. Educause Review Online. Available online: https: / / er.educause.edu/articles/2013/10/exploring-students-mobilelearning-practices-in-higher-education (accessed on 20 April 2018).

35. Al-Fahad, F.N. Students' attitudes and perceptions towards the effectiveness of mobile learning in King Said University, Saudi Arabia. Turki. Online J. Educ. Technol. 2009, 8, 111-119.

(C) 2018 by the authors. Licensee MDPI, Basel, Switzerland. This article is an open access article distributed under the terms and conditions of the Creative Commons Attribution (CC BY) license (http:/ / creativecommons.org/licenses/by/4.0/). 